\title{
How good is our public library service? The evolution of a new quality standards framework for Scottish public libraries 2012-2017.
}

REID, P.H. 


\title{
How good is our public library service? the evolution of a new quality standards framework for Scottish public libraries 2012- 2017
}

\author{
Professor Peter H. Reid \\ Robert Gordon University, Aberdeen
}

\begin{abstract}
The current challenging environment for public libraries has resulted in an ever greater need to demonstrate and evidence the quality of library provision as well as value and impact of these services on society. Research, conducted on behalf of the Scottish Library and Information Council, reviewed the previous quality standards mechanism used in Scotland and resulted in the creation of a new framework. Data were gathered through a systematic review of all published quality audits of Scottish public libraries, focus groups with heads of service, and impact workshops with library staff. The findings resulted in the creation of a new approach to assessing and evaluating the quality of provision as well as value and impact of Scottish public libraries.
\end{abstract}

Keywords: Public libraries, quality enhancement, quality frameworks, quality standards, value, impact, Scotland

\section{Introduction}

In 2005-06, the Scottish Library and Information Council (SLIC) developed the Public Library Quality Improvement Matrix (PLQIM) as the first bespoke quality standards for public libraries in Scotland. Much of Scotland's early public library legislation mirrors that in England and Wales, although it is governed by different Acts of Parliament. In particular, the 1964, Public Libraries and MuseumsAct does not apply in Scotland; rather, it is the Local Government (Scotland) Act 1973 which is the principal source of legislative guidance on libraries in Scotland; in 1994 and to facilitate further local government reorganisation the Local Government (Scotland) Act 1994 reincorporated the library provision and places local authorities under a duty to 'secure the provision of adequate library facilities for all persons resident in their area'. In the years since the Act was passed the definition of the word 'adequate' has been a source of much debate and often political tension in some local authorities and, on occasions, significantly impacted on the direction of this research.

Scotland is not alone in having wording of this nature. The Public Libraries and Museums Act 1964, covering England and Wales had similar phrasing, using the term "a comprehensive and efficient library service for all persons desiring to make use thereof". In recent years, financial pressures have resulted in many public library closures in England with campaigners seeking judicial reviews of such plans in Gloucestershire (2011), Somerset (2012), Lincolnshire (2014) and, most recently, Northamptonshire (2018). Quality standards in England were introduced in 2001 as 'Comprehensive, Efficient and Modern Public Libraries' and were revised in 2004, 2006, 2007 and finally in 2008. This was then replaced by National Indicator NI09: Use of Public Libraries before its abolition in 2010 by the Coalition Government and, by doing so, quality measure has largely been abandoned. In Wales, an evolving approach has been adopted to public library quality standards with the iterative quality framework, currently Connected and Ambitious Libraries: the sixth quality framework for Welsh libraries 2017-18. 
In an attempt to provide guidance on how to interpret the word 'adequate', the Convention of Scottish Local Authorities (COSLA) developed a series of Quality Standards for public libraries during the 1980s and 1990s. However, it was in the early 2000s that the Scottish Library and Information Council (SLIC) started to look more seriously at quality measurement, standards and enhancement. The Scottish Library and Information Council is the independent advisory body to the Scottish Government on library and information services and it was established in 1991. It is funded through Scottish Government funding, member subscriptions and contributions from the National Library of Scotland. It exists to provide a leadership focus for Scottish library and information services, to monitor standards of provision of services and advise the Scottish Government and ministers on all matters concerning library and information services.

In 2004, the Scottish Library and Information Council began developing a set of quality standards for Scotland's public libraries. This was eventually published as the Public Library Quality Improvement Matrix (PLQIM). During 2005-2006, a number of local authority library services went through a pilot for the mechanism before its final implementation in 2007. Between 2007 and 2012, the majority of Scottish local authorities had taken part in at least one instance of the quality improvement audit with many going through multiple indicators and, in some cases, more than one cycle of review.

The Public Library Quality Improvement Matrix had an impact beyond Scotland, most particularly in the Australian State of Victoria, where the Public Libraries Victoria Network, in conjunction with Australian Continuous Improvement Group and representatives of the Scottish Library and Information Council, worked to create Being the best we can be, a selfassessment and peer-review framework to provide tools to assist Victorian public libraries in meeting their service obligations and objectives. The Framework was inspired by PLQIM and strongly emphasised requirements of services delivered by public libraries, and how they can be delivered to support wider government policies.

In Scotland, by 2012, there was a growing acknowledgement that a review of the framework was required. Standards of service delivery had improved over the period since PLQIM's introduction. The context within which public libraries operate has also changed due in part to advances in technology, while the political and economic climate has also had an impact on services. Additionally, there was a perception that it was becoming 'too easy' to attain the highest ranking of 'Excellent'. It was, therefore, considered timely to review the PLQIM process as a whole to ensure the continued relevance of the mechanism for public library services and, more specifically, to re-evaluate the criteria by which public libraries are measured to ensure the provision of adequate services.

In 2013, Information Management staff at Robert Gordon University, Aberdeen (Professor Peter Reid and Ms Caroline Whitehead), were commissioned to undertake a review of the PLQIM process, and in particular to determine the extent to which the quality indicators and levels were (a) robust and meaningful, and (b) in need of revision to reflect the improvement in standards in library services demonstrated in evaluation reports thus far. This article outlines the process of review, the subsequent development of a new framework of quality standards, and their implementation, as well the alignment and adjustments made within the context of the development of Ambition and opportunity, the national strategy of Scottish public libraries, 2014-2020.

\section{Literature review}


Examination of the impact of public libraries is not a new phenomenon. It has existed in many forms, both implicit and explicit, for many decades and it can be argued that those early British advocates of placing public libraries on statutory footing - such as William Ewart in the 1840s and 1850s - were strong promoters of what might be described in twenty-first century parlance as the 'transformational capacity' which 'free-at-the-point-of-use' public libraries had on individuals and society more generally.

I have now the satisfaction to see in England, springing up as the result of a measure which I introduced numerous Free Public Libraries, affording the means of gratuitous and open instruction to thousands of readers in England, as I hope thereafter to see them in Scotland' (Shirley, 1947: 327)

'Performance measurement' in libraries emerged particularly strongly in the 1970s with the work of DeProspeo, Altman and Beasley (1973), although later was often replaced by the term 'output measure', although both phrases have been used interchangeably. In 1989, Van House noted that this was often tied to a

Growing demand for accountability in the public sector coupled with an increased sophistication among librarians and other managers. As quantitative methods, program evaluation and evaluation research have spread through the public sector, and accountability requirements have tightened, librarians have adopted these methods to remain competitive with other organizations seeking the same resources. (Van House, 1989: 269).

Following from this, Childers and Van House undertook research, in the United States, in the late 1980s, examining library effectiveness variables focusing seven different constituencies: library directors, library staff, the members of friends' groups, users, trustees, local officials and community leaders. Following extensive work and literature reviewing, they identified sixtyone potential indicators of library effectiveness before undertaking a questionnaire of libraries across the United States, using a stratified sample. Six indicators appeared in the top-ten rankings of all seven constituent groups: convenience of hours, range of materials, staff helpfulness, services suited to the community, and quality of materials.

\section{Going beyond metrics}

In 2001, Toyne and Usherwood explored this theme by highlighting that much of the evaluation that went on in public libraries was limited to 'counting the number of book issues, and there is little evidence of attempts to consider the impact of those "issues" on individuals or groups in the community. In other words, the service still tends to measure what is measurable and consequently miss what is important' (Toyne and Usherwood, 2001, 149).

Looking at value and impact solely in economic terms can run the risk of demeaning libraries 'intellectual and social foundations' (McMenemy, 2007: 273). The economic approach has been explored principally by Aab $\varnothing$ (2005) in work on a contingent valuation study of Norwegian public libraries as well as by others, such as Barron et al (2005) on the economic value of libraries in South Carolina, as well as in other internal local government studies in various countries. A number of value and impact studies for libraries, focusing on qualitative evidence, have purposefully excluded the economic value methods (such as Vakkari and Serola, 2012) because such studies conceptualise benefits differently.

Several studies also highlight a much-rehearsed theme in library science literature, namely the bluntness of many of the quantitative measures of library performance: 
How can book issues in an inner city community tells us anything of what those books are being used for when borrowed? Certainly an element of popularity of the service can be gleaned from statistics that show number of registered library users in a community and from this statistic the number of active users. However these cold, hard facts tell us nothing of what the library is achieving for these people. (McMenemy, 2007: 274).

The articles sums this up by posing one of the central questions of value, impact and quality assessment: what do these 'cold, hard facts' tell us about what the library is achieving for people? This has become particularly significant given that, as Goulding noted, despite the public being generally predisposed to and broadly positive about libraries, many commentators, socially, politically and economically, portray them as either being at crisis point (Goulding, 2006: 4) or lacking relevance to contemporary society because of a jaundiced and out-dated view of what they do (a trend particularly evident since the economic downturn in 2008).

Vakkari and Serola (2012) charted the transition in approaches to measuring the impact of public libraries away from (purely) quantitative measures: '[i]nstead of counting the number of book loans, for example, the emphasis is on how the loans benefit readers' (Vakkari and Serola: 2012: 37). In doing so, this built on the work of Rubin (2006), Durrance, Fisher and Hinton (2005), Hernon and Dugan (2002), to describe the shift in the 'evaluation paradigm...from counting the outputs to observing the outcomes' (Vakkari and Serola, 2012: 37). They highlight that studies of the outcomes of public libraries are often divided into two broad categories focusing on either specific library programmes or services on the one hand, or the general benefits to life as a result of library use.

\section{Qualitative approaches emphasising community enrichment}

There are several important studies which have moved away from the bluntness of quantitative tools such as visits or issues (important though they remain) to look at broader qualitative aspects such as notions of benefit, impact, community enrichment or societal gain. Matarasso (1998) was an early advocate of exploring measures of impact more widely:

Existing library performance indicators [e.g. number of books issued] are an inadequate management tool for the library of the $21^{\text {st }}$ century. New performance indicators must be developed to reflect the broad social impact of the most imaginative library services and to encourage others to take a wider review of their mission. (Matarasso, 1998: v)

Matarasso was reflecting an emerging realisation that a new emphasis on the 'social impact' of libraries was needed; see Greenhalgh et al, 1995; Kerslake and Kinnel, 1997; Harris, 1998 whose work all attempted to look beyond established library functions and the one-dimensional assessments of performance based on book issues. This was also echoed by Linley and Usherwood in their work on the social capital of libraries with their social audit of library services in Newcastle and Somerset, which explored, through qualitative data collection and analysis, community enrichment and benefit in a number of areas including societal role, community ownership, education role, economic impact, reading and literacy, developing confidence in individuals and communities, and equity in service delivery. (Linley and Usherwood, 1998). 
Aspects associated with societal value and impact have been explored by a number of pieces of research including Rankin and Brock (2012), who highlighted that:

Libraries give identity to a community and should provide opportunities for everyone within that community. Libraries are a social leveller and, compared with some other types of cultural activity, can reach a much broader range of age groups, genders, and ethnic and social backgrounds. (Rankin and Brock, 2012: 5)

Similarly, McClure and Bertot (1998) studied the benefit and impacts of public libraries in Pennsylvania in research which attempted to determine how the use of public libraries was valuable or beneficial to users and to their communities. In a survey of 13,000 users, they defined significant benefit or impact as being (from users' perspectives) a substantial improvement in their personal, educational, economic or other significant aspects of their lives. Halpin et al (2012) used the Delphi method in order to gather stakeholders' opinions and perspectives on the value of public libraries in the digital age and concluded that a humanrights based approach could facilitate and support arguments in favour of public library provision. Other studies, such as Lance et al (2001) examined the impact of the public library in the life of a patron (surveying over 5,000 US library users) and how the library responded to needs in the user or community groups, such as literacy, business and career information, the library as place, general information, information literacy, and local of family history. Respondents assessed whether the library's service had produced the desired outcome.

Rowley, in an opinion piece, highlights that 'public sector policymakers have been preoccupied with quality, performance and impact initiatives, which constrain and define the strategic and operational objectives of public sector' bodies (Rowley, 2005; 508) and that managers often have find a way through an increasingly complex 'quality maze'. Additionally, this article highlights that much of the literature focuses on individual initiatives, with little reference to the wider quality management context. To this can be added the gap in the literature associated with the creation and use of quality standards and how these can be used by library services to measure the value and impact of their services to individuals and communities.

The factors outlined in this review of the literature informed context, and to a certain extent the research design of the project in Scotland to develop meaningful quality standards for public libraries in Scotland which emphasised the value and impact of services and the importance of gathering evidence in these regards as part of the quality reviews.

\section{The research project}

As indicated previously, by 2012 there was a belief that it was timely for the Public Library Quality Improvement Matrix, and the reviews which had been undertaken required review to ensure that the mechanism remained robust and appropriate. A research team, comprising Professor Peter Reid as principal investigator and Caroline Whitehead as research assistant was commission by the Scottish Library and Information Council to undertake this work.

The objectives for the project were:

1. To undertake a systematic review of all Public Library Quality Improvement Matrix reports undertaken;

2. To evaluate the process by which the Public Library Quality Improvement Matrix was implemented;

3. To analyse the appropriateness and relevance of the seven Quality Indicators (QIs), levels and benchmarks; and 
4. To identify recommendations for the recalibration of the matrix and toolkit to ensure continued relevance and appropriateness of the mechanism.

As will be outlined subsequently, the fourth objective resulted in the research project changing focus when it became clear that both the Scottish Library and Information Council (as funders) and the Heads of Scotland's Public Library Services (as stakeholders) had a clear appetite for the mechanism to be significantly revised and updated.

The appetite for a full-scale revision of the mechanism was tied to factors outlined above, but was also due to the fact that Scottish legislation refers to the provision of 'an adequate public library service'. At the time of this research project was being conducted, a number of local authorities were seeking to make cuts to their library provision. These were invariably met by strong and vocal public campaigns which generated a great deal of publicity. In particular, the proposed cuts in Moray became something of a cause célèbre in the Scottish media during much of 2013 and also featured in the national press including the BBC and the Guardian. Many stakeholders, both local authorities and members of the public, therefore, looked to the review of PLQIM to inform what an 'adequate' service could look like. However, there was a clear feeling amongst heads of public library services and in the research team that both the review of the past mechanism and the creation of a new one had to be completely objective and to ignore, as far as possible, particular financial or political challenges that libraries were facing at that point. The stakeholders were clear that the framework had to be a robust mechanism about for measuring their quality and impact not a political statement.

\section{Methodology}

In a work of this nature, it is inevitable that a systematic review was required, because the research project was concerned with examining (a) the mechanism by which a process has been undertaken, and (b) the outcomes which emerged from that process. In both of these elements, therefore, the focus was on the critical examination and analysis of pre-existing evidence rather than on the collection or generation of new empirical evidence by the research team. In essence, therefore, the majority of the work undertaken by the research team was evaluative data analysis rather than primary data generation (although some new data were generated as outlined later).

The first three objectives, examining the reviews to date, the process and the relevance of the quality indicators were inextricably linked and were examined together in a holistic fashion. The principal focus of the research project was, therefore, centred on the critical evaluation of published material: either the PLQIM toolkit itself, the quality indicators or the summative published reports after audits had been completed. All other publicly-available data connected with the PLQIM process have also been scrutinised.

It can be said, therefore, that the basic conceptual framework for approaching the research was broadly akin to that of a systematic review of literature, whereby data which have been collected, analysed, interpreted and published (in this case by SLIC as the corporate author of the PLQIM reports) are appraised critically and systematically by an independent research team to assess the robustness and rigour of what has been done previously. In essence, therefore, the project examined all aspects of the PLQIM process (including all of the summative reports) and aggregated the findings from this critical appraisal into a body of evidence about the appropriateness and robustness of PLQIM, and about the lessons which can be learned to enhance both mechanism and process.

\section{Data collection: the reviews}


The 57 published reports of PLQIM reviews undertaken between 2005 and 2012 became the primary focus for systematic review, with each being scrutinised closely by the research team. The following table outlines the authorities reviewed (some are repeated because they undertook different quality indicators in different years).

Table 1: Public Library Quality Improvement Matrix Quality indicators

\begin{tabular}{|l|l|}
\hline Quality Indicator 1: & Access to information \\
\hline Quality Indicator 2: & Personal and community participation \\
\hline Quality Indicator 3: & Meeting readers' needs \\
\hline Quality Indicator 4: & Learners' experiences \\
\hline Quality Indicator 5: & Ethos and values \\
\hline Quality Indicator 6: & Organisation and use of resources and space \\
\hline Quality Indicator 7: & Leadership \\
\hline
\end{tabular}

\begin{tabular}{|l|l|c|}
\hline Year & Authorities & No. \\
\hline 2005 & East Renfrewshire | West Dunbartonshire & 2 \\
\hline 2006 & $\begin{array}{l}\text { Fife | Highland | Inverclyde | Perth and Kinross | Scottish Borders | } \\
\text { Stirling }\end{array}$ & 6 \\
\hline 2007 & East Lothian | Glasgow | Inverclyde & 3 \\
\hline 2008 & $\begin{array}{l}\text { East Dunbartonshire | East Lothian | East Renfrewshire | Edinburgh | } \\
\text { Fife | Inverclyde | Moray | North Ayrshire | Shetland | South } \\
\text { Lanarkshire }\end{array}$ & 10 \\
\hline 2009 & $\begin{array}{l}\text { Argyll and Bute | Comhairle nan Eilean Siar | Dumfries and Galloway | } \\
\text { Dundee | Falkirk | Highland | Midlothian | Orkney | Stirling }\end{array}$ & $\mathbf{9}$ \\
\hline 2011 & $\begin{array}{l}\text { Aberdeen (and Aberdeen follow-up) | Aberdeenshire | Dumfries and } \\
\text { Galloway | East Renfrewshire | Renfrewshire | South Lanarkshire | } \\
\text { West Dunbartonshire | West Lothian }\end{array}$ & $\mathbf{8}$ \\
\hline $\mathbf{2}$ & $\begin{array}{l}\text { Lothian | Fife | Highland | Inverclyde | Midlothian | Moray | Perth } \\
\text { and Kinross | South Lanarkshire | Stirling | West Dunbartonshire }\end{array}$ & 14 \\
\hline & $\begin{array}{l}\text { Aberdeenshire | East Renfrewshire | Midlothian | Moray | Shetland } \\
\text { Total number of reports (including pilots) which have systematically reviewed }\end{array}$ & 57 \\
\hline
\end{tabular}

\begin{tabular}{|l|l|l|l|l|l|l|l|l|}
\hline Quality indicators undertaken by date and authority \\
\hline Authority & 2005 & 2006 & 2007 & 2008 & 2009 & 2010 & 2011 & 2012 \\
\hline Aberdeen & & & & & & $1^{1}$ & 2 & \\
\hline Aberdeenshire & & & & & & 1 & 3,4 & 2 \\
\hline Angus & & & & & & & & \\
\hline Argyll \& Bute & & & & & $1,2,3,4$ & & & \\
\hline Clackmannanshire & & & & & & & & \\
\hline Eilean Siar & & & & & $1,2,3,4$ & & & \\
\hline $\begin{array}{l}\text { Dumfries \& } \\
\text { Galloway }\end{array}$ & & & & & 1,5 & $2,3,4$ & 6,7 & \\
\hline Dundee & & & & 3,5 & & 2,6 & & \\
\hline
\end{tabular}

${ }^{1} \mathrm{Q} 1$ resubmission in the same year. 


\begin{tabular}{|l|l|l|l|l|l|l|l|l|}
\hline East Ayrshire & & & & & & & & \\
\hline $\begin{array}{l}\text { East } \\
\text { Dunbartonshire }\end{array}$ & & & & 1,5 & & & & \\
\hline East Lothian & & & 1,3 & & & & 2,6 & \\
\hline East Renfrewshire & 1,2 & & & & & $5,6,7$ & & 3 \\
\hline Edinburgh & & & & $\begin{array}{l}1,2,3,4, \\
5,6,7\end{array}$ & & & & \\
\hline Falkirk & & & & 1,6 & & & & \\
\hline Fife & & 4 & 4 & 3 & & & 6 & \\
\hline Glasgow & & & & & & & & \\
\hline Highland & & 6 & & & 3,5 & & 7 & \\
\hline Inverclyde & & 3 & 4 & & & & 1 & \\
\hline Midlothian & & & & & 3,6 & & 1,2 & 4,5 \\
\hline Moray & & & & 2,6 & & & 3,5 & 4,7 \\
\hline North Ayrshire & & & & 2,3 & & & & \\
\hline North Lanarkshire & & & & & & & & \\
\hline Orkney & & & & & $1,2,3,4$ & & & \\
\hline Perth \& Kinross & & 7 & & & & & 2,3 & \\
\hline Renfrewshire & & & & & & 1,6 & & \\
\hline Scottish Borders & & $1,2,3,4$, & & & & QI 2, & & \\
\hline Shetland & & & & $1,2,3,4$, & & & & 3,4 \\
\hline South Ayrshire & & & & & & & & \\
\hline South Lanarkshire & & & & 1,6 & & $3,4,5$ & 2,7 & \\
\hline Stirling & & 5 & & & 1,4 & & 3 & \\
\hline $\begin{array}{l}\text { West } \\
\text { Dunbartonshire }\end{array}$ & $5,6,7$ & & & & & $1,3,4$ & 6 & \\
\hline West Lothian & & & & & & 3 & & \\
\hline
\end{tabular}

\section{Data analysis from reviews}

Several rounds of analysis of the reports were undertaken. The preliminary scrutiny of the reports was done at the outset of the research project to enable the research team to gain indepth familiarity with the style and content routinely found in the reports. It was also used to identify preliminary issues to be examined further subsequently. The issues which emerged initially during this first round can largely be described as internal ones, that is to say primarily connected with the reports themselves as documents. These included:-

(a) Issues of consistency connected with the structure, format and language of reports

(b) Issues associated with descriptive narrative rather than evidence-based reporting A second round of scrutiny of the reports was then deployed to examine the reports more widely within the context of the process by which PLQIM is implemented. This second scrutiny of the reports also highlighted a number of issues:-

(a) The role of self-evaluation by library services in the process

(b) The role of the peer-review visits as a tool for assessing service performance

(c) The role of peer reviewers in the process

(d) The consistency in application of toolkit

(e) The consistency in outcomes from the process

(f) The appropriateness of the quality indicators and the level descriptors

These issues were then brought forward into the examination of the process with key stakeholders. 


\section{Key stakeholder focus group}

An important part of the methods for data collection was a focus group held with key stakeholders. During the entire process a number of discussions and dialogues were held with various key informants in the Scottish library sector (including Scottish Library and Information Council, CILIP Scotland as the professional body and the heads of library services). These groups had working knowledge of PLQIM as a process and had particular insight into it as either a participant in peer-review or as a manager whose services had undergone the review process. These dialogues were valuable to the research team as they have, generally, reinforced the issues identified above and about which further findings are presented later. This led to a focus group, held in Perth comprising 21 (of the 32) heads of public libraries in Scotland (or a substitute attending on their behalf).

Given the seniority of the people involved in this focus group and the importance of obtaining their honest assessment of any issues or challenges associated with PLQIM, the principle of 'Chatham House Rules' was applied, namely that information disclosed during a meeting may be reported by those present, but the source of that information may not be explicitly or implicitly identified. The focus group was not recorded but extensive notes were taken by the research team.

\section{Data analysis from key stakeholder focus group}

Very valuable information was gained through this focus group and the views of the heads of service played a significant part in shaping the review. All were open-minded and unbiased; they did not attempt to influence the review (which they welcomed). The focus groups resulted in data clustered around six key themes:

1. The fundamental value and benefits of PLQIM

2. The levels and outcomes (and perceptions about the award of the top scores)

3. The training of assessors

4. The role PLQIM has in informing the definition of an 'adequate' public library service

5. The link between the PLQIM process and the PLQIF Awards

6. The role of independent assessors

There was also important dialogue about perceptions of 'grade inflation' amongst the professional public library community in general and amongst the Heads of Service in particular, which had been one of the fundamental reasons for the commissioning of the research in the first instance.

\section{Data collection from independent focus group}

As part of the research, an independent focus group was carried out involving MSc Information and Library Studies students at Robert Gordon University. This was done following a class on performance and quality management in which PLQIM, along with other comparable mechanisms adopted in other parts of the information and library sector, was examined. The purpose of the focus group was to gather (independently of the research team or those involved directly in the PLQIM process) opinion as to the extent to which the reports could be regarded as robust and rigorous by those with some knowledge of the sector, but without extensive prior knowledge of the processes.

The sub-groups within the focus group were not informed of any of the research team's findings from either the analysis undertaken on the reviews or the outcomes of the key 
stakeholder focus groups, but were simply asked to consider the following questions in relation to the reports:

1. Do you consider the process to be robust on the basis of the evidence in the reports?

2. Do you agree with the judgments and grades which the PLQIM reviewers reached?

3. Are the examples of good practice credible and appropriate?

4. Are the areas for improvement credible and appropriate?

In addition to these specific questions on the reports, the groups were also asked to consider any shortcomings they could identify from the reports and how they believed PLQIM as a process could be modified.

Each of the sub-groups considered that the process had been robust, deploying multiple methods of data collection during visits (documentation, statistical data, discussions with staff, stakeholders and users as well as observational visits to specific locations within the authority). These multiple sources of evidence were highly regarded and were fully in line with sources of evidence outlined in the PLQIM Toolkit (pp13-14). The groups reported that there was clear corroboration between (i) documentary and statistical information, (ii) discussions, interviews and focus group meetings with staff and others, and (iii) observational visits. The latter were also perceived to be a strength in the process.

The focus groups generally agreed with the overall outcomes on the basis of the evidence presented in the reports. There were two instances where the sub-groups felt that the overall outcome had been 'generous'. However, both of the groups which indicated dissent from the outcome believed that they did not have enough evidence from the reports to make a categorical decision. This was echoed by other sub-groups. In general, the prevailing feeling of the focus group as a whole was that the reports, although robust and reliable, did not cite enough evidence in the narrative to make the outcome decisions and levels awarded as transparent as they could be. This validated issues which the research team had previously identified.

\section{Triangulation between reviews, stakeholder and independent focus groups}

The three principal elements of data collection, the scrutiny of the PLQIM reviews, the stakeholder focus group and the independent focus group, together with their interim analysis stages, led the research team to triangulate the evidence gathered. A remarkable degree of consistency over the key issues emerged from this.

All sources evidence highlighted the robustness of the process and mechanism as tool for peerassessing the quality of public libraries in the areas covered by the indicators. Although there was clear agreement that multiple sources of evidence had been scrutinised by the reviewers, there was a feeling that, in some places, this evidence could be made more explicit. One report, for example, indicated 'there are a large number of local events that the library service taps into, and it has developed strong links with community groups' (PLQIM Report [Library service redacted], 2012) but this is not elaborated on explicitly nor supported by examples. Another noted 'there are very good community heritage and local and family history collections' (PLQIM Report [Library service redacted], 2011) without further evidence being provided explicitly in the report. These were both independently highlighted by the stakeholder and independent focus groups with a feeling that these were 'main-stream' for public libraries and consequently the process failed to provide appropriate evidence to support statements.

This led to the major issue, associated with perceived 'grade inflation' in terms of the final ranking given under each quality indicator assessment. The desk-based research and the two focus groups felt a number of things which were deemed to be examples of good practice had, 
in fact, become main-stream and this reflected and reinforced the value of the review being undertaken. It was frequently said in the key stakeholder focus group 'what was exception in 2005 is now mainstream and doesn't justify an Excellent' (Excellent being the highest score awarded in assessments). Grade inflation of this kind (or at least a perception of it) is often common with such quality frameworks.

There was some also unease about certain aspects (often but not exclusively connected with online facilities and provision) and their worthiness of the higher scores. Again, this reinforced in the minds of the focus group participants the importance of updating and developing quality improvement mechanisms such as PLQIM to ensure they keep pace with change and, indeed, with service improvements. There was a sense, amongst all participants and corroborated in the desk-based review work, that the levels and indicators required review, in order to ensure that things deemed as 'excellent' or 'very good' when the mechanism was created but which were by then widely-accepted as standard were graded as such. This confirmed issues which the research team had identified in respect of both the wording of the levels and indicators and their practical application in reviews over the period PLQIM has been in operation.

Overall, therefore, the main suggestions which emerged centred around standardising more explicitly the section on the process, and on providing greater contextual and evidence-based commentary to help support the transparency of the outcomes. The focus group was generally satisfied that the areas of strength were appropriate and that areas for improvement were also relevant although, in respect of the latter, further evidence leading up to these recommendations would be beneficial as there was a feeling that preceding text in the report tended to focus on the good practice. The final point made by the focus group in relation to the overall improvement of the process was connected with the possibility of an independent auditor as part of the review team. This also broadly confirmed issues identified by the research team.

\section{Results}

There was evidence to suggest that the purpose of PLQIM has shifted since its inception. The results of the study showed that the PLQIM process had become richer and deeper and, perhaps, slightly more complex than the initial conception. The process was certainly beneficial in assisting library services' understanding of what constitutes 'adequate' performance. Selfevaluation by local authority library services strongly encouraged the importance of demonstrating value and impact but the process did not always do justice to this. The benefits of the framework for services as a tool for, inter alia, benchmarking, performance management, service review and improvement planning were evident and indisputable.

There was strong evidence from the research that the number of Quality Indicators - seven was too many. This had come to be considered burdensome by local authority library services and there was a general feeling that five would be more manageable and appropriate for library services to address, either during one round of evaluation over a year, or over a rolling period of perhaps three years.

In terms of grades awarded, the research showed that there has been a shift over the years. The bulk of the grades (up to 2009) were spread across levels 3 -5; from 2009 onwards the majority of grades are spread across levels $4-6$. This has been accompanied by a significant increase in the number of 'Very Good's and 'Excellent's. This may well, of course, have reflected a general improvement in the provision and evidence would suggest that this is certainly a contributory factor but, nevertheless, some issues do exist with this upward trajectory. It was evident throughout the research - both in formal and informal discussions - 
that there was a perception it was becoming easier to gain an 'Excellent' (level 6) grading. However, the evidence showed that this has only been achieved as an overall grading in 7 instances out of a total of 125 evaluations, i.e. $5.6 \%$. There was, however, evidence to indicate a steady increase in the overall grading of 'Very Good' (level 5) over time, with of 18 'Very Good's in 2011 being awarded out of a total of 20 Quality Indicator evaluations that year, amounting to $90 \%$ for that year. Overall, the number of 'Very Good' (level 5) grades awarded totalled 49 (39.2\%) since PLQIM inceptions.

Table 4: Public Library Quality Improvement Matrix gradings over time

\begin{tabular}{|l|l|l|l|l|l|l|l|l|}
\hline & 2005 & 2006 & 2007 & 2008 & 2009 & 2010 & 2011 & 2012 \\
\hline 6 Excellent & & & & & & 2 & 2 & 3 \\
\hline 5 Very Good & 3 & & 1 & 10 & 5 & 10 & 18 & 2 \\
\hline 4 Good & 6 & 1 & 3 & 14 & 8 & 8 & 2 & 3 \\
\hline 3 Satisfactory/Adequate & & 10 & & 3 & 10 & & & \\
\hline 2 Weak & & 1 & & & & & & \\
\hline 1 Unsatisfactory & & & & & & & & \\
\hline
\end{tabular}

Table 5 Reviews conducted by Quality Indicator and Level attained

\begin{tabular}{|c|c|c|c|c|c|c|c|}
\hline Q & $\begin{array}{l}\text { Tot } \\
\text { al }\end{array}$ & $\begin{array}{l}\text { Level 1: } \\
\text { Unsatisfact } \\
\text { ory }\end{array}$ & $\begin{array}{l}\text { Level } \\
2: \\
\text { Weak }\end{array}$ & $\begin{array}{l}\text { Level 3: } \\
\text { Satisfactor } \\
\text { y }\end{array}$ & $\begin{array}{l}\text { Level } \\
\text { 4: } \\
\text { Good }\end{array}$ & $\begin{array}{l}\text { Level 5: } \\
\text { Very } \\
\text { Good }\end{array}$ & $\begin{array}{l}\text { Level 6: } \\
\text { Excelle } \\
\text { nt }\end{array}$ \\
\hline $\begin{array}{l}\text { QI } 1 \text { Access to } \\
\text { Information }\end{array}$ & 21 & & & 4 & 8 & 9 & \\
\hline $\begin{array}{l}\text { QI } 2 \text { Personal and } \\
\text { community } \\
\text { participation }\end{array}$ & 19 & & & 2 & 3 & 13 & 1 \\
\hline $\begin{array}{l}\text { Ql } 3 \text { Meeting } \\
\text { Readers Needs }\end{array}$ & 24 & & 1 & 2 & 12 & 7 & 2 \\
\hline $\begin{array}{l}\text { Q1 } 4 \text { Learners } \\
\text { Experiences }\end{array}$ & 19 & & & 4 & 8 & 5 & 2 \\
\hline $\begin{array}{l}\text { QI } 5 \text { Ethos and } \\
\text { values }\end{array}$ & 14 & & & 2 & 5 & 6 & 1 \\
\hline $\begin{array}{l}\text { QI } 6 \text { Organisation } \\
\text { and use of } \\
\text { resources and } \\
\text { space }\end{array}$ & 17 & & & 5 & 7 & $\begin{array}{l}2 \\
\text { level } 4 / 5 \\
-3\end{array}$ & \\
\hline QI 7 Leadership & 11 & & & 4 & 2 & 4 & 1 \\
\hline Totals & 125 & & 1 & 23 & 45 & 49 & 7 \\
\hline
\end{tabular}

The significant increase in 'Very Good' (level 5) grade may have resulted from a number of factors, not least improvements and developments in library services during the time of PLQIM, and the impact of funding for developments through the Public Library Improvement Fund. It was suggested there was a perception that grading over time has become a little 'more generous'. This has been difficult to ascertain due to the lack of detailed evidence included in the final summary reports, or available to the research team.

However, there was evidence that grading has not always been consistent with the benchmarks. For example, it was instructive to compare the grading of two library services: 
one was a large urban, the other a medium rural one; both were observed to have challenges relating to old, traditional buildings that required significant adaptations and modernisations to suit requirements of the Disability Discrimination Act and the technological and space requirements of a modern library service. Comparison of the reports for these services showed some discrepancy in relation to the benchmarks. In the summary reports relating to Quality Indicator 6 (Organisation and use of resources and space), the smaller library service was graded as Satisfactory (level 3) for accommodation and facilities despite having made significant refurbishments when opportunities arose (interpreted normally as Good, (level 4)) and also had an award-winning new library design (interpreted normally as Very Good (level 5)). The larger library service while being graded as Satisfactory (level 3) for accommodation and facilities had more significant access issues, with particular challenges in adapting old buildings. The outcome for the larger service may well have been accurate, but that for the smaller one appears low.

This highlights one of the difficulties encountered by the research team; it was been difficult to make accurate assessments of grade according to benchmarks, because of the lack of detailed evidence in the reports to judge the overall grade. In both cases, there may well have been further mitigating evidence to support the grade awarded, but this is not apparent from reading the summary reports.

While everyone always wished for a 'good' grade as a result of a review, it could sometimes be more useful and effective (in terms of feedback for local authorities and other stakeholders) to be awarded a realistic grade, however disappointing this may have felt at the time. For example, a small urban library service was graded as Weak (level 2) during a review conducted in the early stages of the pilot for PLQIM. This service had suffered from under-investment for some time. The reports of subsequent PLQIM reviews show that this service has made great improvements through increased investment to gain 'Good' and 'Very Good' grades for aspects of their service.

The research into the Public Library Quality Improvement Matrix was wide-ranging in its scope but focused in its consideration. The framework mechanism and process as observed by the research team was found to be robust and rigorous and one which government, public library services and the library users could broadly have confidence in. It was seen as commendable that the process focused on outcomes, that it involves self-evaluation and reflection as well as strongly emphasising continuous enhancement and peer-review.

However, as with all such mechanisms there was scope for enhancing it further. In particular, there was clear need to modify the quality indicators and the level benchmark statements to reflect contemporary practice better. Further enhancement of certain procedural aspects was required in order to make the process more robust. These include enhancing the toolkit for library services, reconstituting the panel of verifiers (but with strong emphasis still placed on peer-review) and by adopting a template approach to the summative reports which draws more heavily on the evidence base.

The research team found that there was strong evidence (such as the generally good levels of engagement from Scotland's local authorities) that PLQIM was a demonstrably beneficial process which focuses on outcomes and on continuous enhancement of quality. It also provided a mechanism for the sharing of good practice across the sector, although this aspect could be further enhanced to exploit more fully the value and impact of library services and the way in which they serve wider national (and indeed local) policy drivers. Additionally, demonstrating value and impact is also about showing what libraries actually do and what 
difference they make to their communities. There was also clear support for PLQIM among the sector as a means of informing a clearer understanding of both what an adequate library service looks like, and also what constitutes adequate performance within those services.

All of these aspects were deemed to be crucial to ensure that PLQIM kept pace with the changes and developments in library services in Scotland. The Scottish Library and Information Council and its then interim Chief Executive Moira Methven were very supportive of the results of the study and accepted the recommendations to recalibrate the entire framework. Consequently, a project which started as an evaluative review aimed at revising the framework was extended in scope and the research team was commissioned to undertake a second phase, the complete redesign of the mechanism and procedures.

\section{The creation of How good is our public library service?}

The principal goals of the second phase fell into six broad areas, the mapping to other performance frameworks, the recalibration of the quality indicators and benchmark statements, various procedural aspects, the training of library staff and assessors, the sharing of good practice and the links with the Public Library Improvement Fund (PLIF), which is administered by Scottish Library and Information Council on behalf of the Scottish Government. Although this was examined and considered in the process of the redesign it became clear that a separate review of PLIF was required (and, subsequently, the same research team were commissioned to undertake this). This subsequent review, therefore, largely falls outside the scope this article.

The recalibration of the quality indicators resulted in their reduction from seven to five; (1) access to information, (2) the readers' experience, (3) the learning culture, (4) individual and community engagement and (5) vision, strategy and continuous improvement. The new quality indicators specified three key themes for each; for example, QI 4, Individual and community engagement, requires exploration of how public libraries develop a sense of identity and pride in civic space, enhance individual and community wellbeing and fostering community heritage and culture. The creation of the new quality indicator five was, perhaps, most significant; this drew on elements previously explored in three of the old PLQIM indicators and brought together much of the managerial and strategic aspects. Although all of the new indicators are judged to be similar in size or scope, it is acknowledged that the new QI5 is probably the most challenging. Its three sub-themes are (i) vision, innovation and management of change, (ii) engagement with community development processes, and (iii) planning, developing and enhancing the library service.

As part of the development of the new quality indicators, the research team sought to align both the content and the approach with other self-evaluation frameworks which were in place in the public sector in Scotland (such as How good is our culture and sport?). Similarly, it was aligned with the National Performance Framework (https://nationalperformance.gov.scot/). The new framework also took account of other central and local government outcomes, the Best Value agenda, and reflected the European Foundation for Quality Management (EFQM) Framework, which is widely used within local authorities.

The original Public Library Quality Improvement Matrix framework had considered a number of options for describing the quality of service provision, and given the practice in local authorities, the description framework currently used by Education Scotland was judged suitable for the needs of library and information services. This assessed performance according to a six point scale. As noted previously in the review of PLQIM, services had developed and advanced significantly from the initial implementation of the framework and there was clear 
support for revising the levels. In effect, what was 'Excellent' (Level 6) in the original framework moved down to become Level 5 in the new one. This necessitated a new articulation for Level 6 . The narrative descriptors are provided in the following table.

\section{Level 6 Excellent}

- Clearly excellent and world-class.

- Very best practice worth disseminating widely beyond the service.

- Users' experiences and achievements are of a very high quality.

- Outstanding delivery of core functions and range of enhanced services.

Level 5 Very good

- Major strengths.

- A high standard of provision, examples of good practice to share

- Any weaknesses do not impact on users' experience.

- Services will take opportunities to improve and strive to raise performance to excellent.

\section{Level 4 Good}

- Important strengths that have a positive impact.

- Few weaknesses that do not have a substantial adverse effect.

- Some examples of good practice

- Services seeking to raise performance further, and addressing areas of improvement.

\section{Level 3 Satisfactory}

- Provision where strengths just outweigh weaknesses.

- Individuals have access to core service provision

- Strengths have a positive impact on individuals' experiences, while weaknesses have some adverse effects on the quality of the users' experiences.

- Services will seek to address areas of improvement while building further on strengths.

\section{Level 2 Weak}

- Weaknesses have a negative impact on the quality of individuals' experiences.

- Such weaknesses diminish individuals' experiences in significant ways.

- The service will need to take structured and planned action to address weaknesses.

\section{Level 1 Unsatisfactory}

- Major weaknesses in provision.

- These weaknesses will require immediate remedial action.

- Individuals' experience is at risk in significant aspects.

- Improvement requires strategic action and support from senior managers. Remedial action may involve work alongside other staff and agencies.

This was not without its challenges and there was considerable debate between the research team and the professional library community about the new level six (and in particular the phrase 'world-class'). Agreement was, however, reached that it had to be highly aspirational and challenging: a target for which public library services could strive for. The previously noted discussion about perceptions of 'grade inflation' also helped reinforce the value of this aspirational approach to level six.

A number of significant administrative and procedural changes were also introduced. These included a stronger planning mechanism for local authorities undertaken their self-evaluation, an encouragement to view How good is our public library service? as an ongoing three-year 
rolling process to complete all indicators, and a new series of templates and documentation both for the self-evaluation and the peer-review. Additionally, and very importantly, staff from the Scottish Library and Information Council ceased participating in the review, with all peerreviewers coming from the wider library profession itself (but not exclusively the public library sector). The new mechanism is not mandatory (nor was the forerunner Public Library Quality Improvement Matrix) but, as the table two above shows.

\section{A critical context}

In some respects, the creation of the new quality indicators and the recalibration of the quality levels was the easy part of the project. More difficult but arguably more important was the broader context in which the new How good is our public library service? framework sits. It is widely recognised that public library services have been in a period of transition from their more traditional role, and moving towards meeting the needs of the twenty-first century. Of course, public libraries have always evolved and changed with the times, but the aftermath of the 2008-09 financial crisis and the concomitant pressure on public service budgets seems to have brought this sharply into focus.

In parallel with the development of How good is our public library service? a national strategy was being created for public libraries in Scotland. This was led by the Carnegie Trust, Scottish Library and Information Council, Scottish Government and others and resulted in the publication of Ambition and Opportunity: a strategy for public libraries in Scotland 2015-20 which provides a clear strategic approach. Ambition and Opportunity highlights that public libraries are trusted guides connecting all of our people to the world's possibilities and opportunities. Scotland's public libraries are also part of shared civic ambition to fulfil the potential of individuals and communities and every step that those individuals and communities fulfilling their potential adds to Scotland's social, economic and cultural wellbeing.

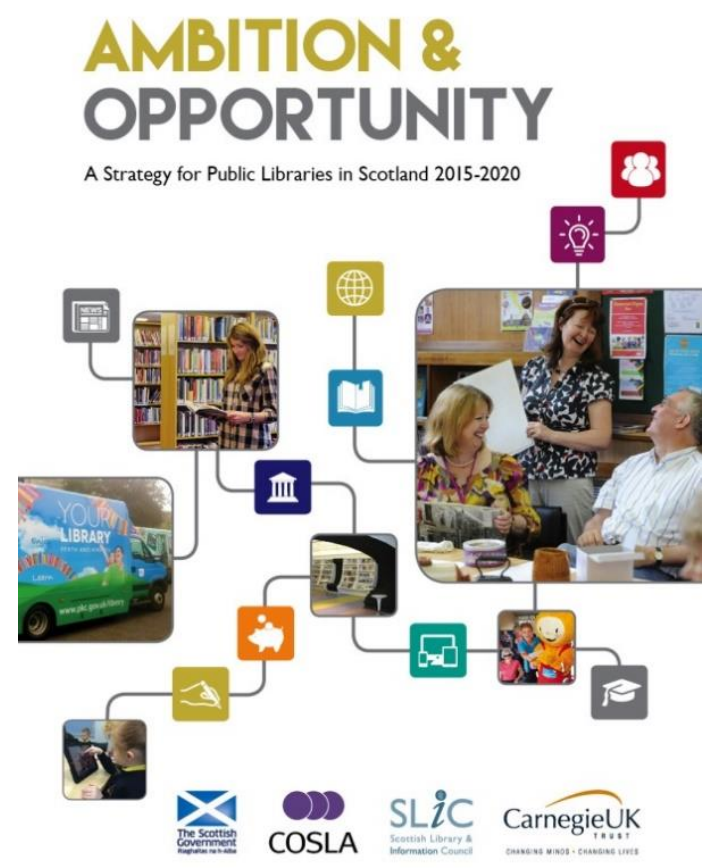

It was important, therefore, that the spirit and aspiration of Ambition and Opportunity was mirrored by How good is our public library service?; the research team spent considerable time drafting the fundamental principles underpinning the assessment of quality in public libraries. 
Much of this was connected to the discussion mentioned previously around the use of the phrase the provision of "an adequate public library service" in the relevant legislation. It was important for How good is our public library service?, as the quality standard, to inform what 'adequate' might look like without creating a one-size-fits-all straitjacket which was inappropriate for Scotland's very different and diverse local authorities. Eventually, the following was agreed with stakeholders:

"For over 150 years public libraries have adapted to user needs and interests, and sought to achieve the underpinning principles in the original 1853 Public Libraries Act (Scotland) "for the Instruction and Recreation of the People" and local authorities continue to have a statutory duty to provide an adequate public library service. This framework was developed, and revised, in order to support and inform the adequate provision of universal public libraries services throughout Scotland. An adequate service is delivered through a planned strategic network of public libraries reflecting core functions:

- Providing universal access to hardcopy and electronic resources which is free, consistent and customer focussed

- Enabling access to resources for reading, information and learning

- Creating social capital by encouraging community involvement and communitybased activity

- Helping to minimise social and digital exclusion

- Supporting learning and information needs in the information society and knowledge economy

- Promoting access to Scotland's cultural heritage and promoting cultural and creative activities

- Encouraging the public to pursue individual interests

- Promoting social justice, civic engagement and democracy

- Working in partnership with other agencies and organisations to offer value added services

- Strategic network provision"

One of the most critical aspects of this statement was the phrase "an adequate service is delivered through a planned strategic network of public libraries..." which had the intention of implying strongly that services and local authorities need to be able to demonstrate how such a network of service points does strategically serve communities, a point particularly important and germane when branch closures are being proposed. Implicit in this statement is the message that a strategic network needs to be more than the places you have left after a round of branch closures for budgetary reasons. This was in line with the approach discussed at the focus group of heads of service. This statement was intended to inform the definition of 'adequate' in the legislation. It is interesting to speculate whether this would be taken into account should a judicial review of provision be brought against any local authority proposing closures. To date, a number of judicial reviews have been threatened but none have actually taken place.

The first review undertaken using How good is our public library? was undertaken in Scottish Borders in January 2016 when Quality Indicator 1 (Access to information) and Quality Indicator 2 (Readers' experience) were assessed. The self-evaluation from the library team at Scottish Borders rated these as being at Level 3 (satisfactory). The peer-reviewers agree with this for quality indicator one but felt that quality indicator two was worthy of a higher grading and so 
it was awarded Level 4 (Good). The first review was monitored by Quality Scotland and other peer-reviewers and panel convenors attended as observers. The process worked effectively although some subsequent minor modifications to the documentation were implemented. Reviews have subsequently taken place across Scotland in a number of authorities.

\section{Conclusions}

The research highlighted both the importance of having a workable quality standards framework and the robustness of the original Public Library Quality Improvement Matrix. It was also necessary to undertake the review, especially because the perception of public library managers about 'grade inflation' proved largely misplaced. It did, however, highlight strongly the way in which services had developed and improved over the period and that a regular and robust regime of self-evaluation and peer-review helped that process of enhancement.

Despite the changing environment in which twenty-first century public libraries find themselves operating, the principles of equity of access to information, the right to know, freedom of expression, the right to participate fully in a democratic society, and a professional and objective ethos remain as fundamental in the digital age as they were when public libraries were first established. How good is our public library service? can, therefore, be viewed in this light as making a contribution to ensuring that the quality of public library services is measured and that they continue to make a positive impact on the communities that they serve.

\section{Reference}

Aab $\varnothing S$ (2005). Are public libraries worth their price: a contingent valuation study of Norwegian public libraries. New Library World 106: 487-495.

Barron DD et al. (2005) The economic impact of public libraries in South Carolina, University of South Carolina, School of Library and Information Science, available at:

http://libsci.sc.edu/SCEIS/final\%20report\%2026\%20january.pdf (accessed October 2018)

Childers T and Van House N (1993) What's good? Describing your public library effectiveness. Chicago: American Library Association.

DeProspero E Altman EA and Beasley KE (1973) Performance measurement for public libraries. Chicago: American Library Association.

Durrance J Fisher K and Hinton M (2005) How libraries and librarians help: Assessing outcomes in your library. Chicago, IL: American Library Association.

Goulding A (2006), Public libraries in the 21st Century: defining services and debating the Future. Gower, Aldershot.

Greenhalgh L, Worpole K and Landry C (1995) Libraries in a world of cultural change. London, UCL Press

Halpin E, Rankin C, Chapman EL, Walker C (2015) Measuring the value of public libraries in the digital age: what the power people need to know. Journal of Librarianship and Information Science 47(1): 30-42. 
Harris K (1998) Open to interpretation: community perceptions of the social benefits of public libraries, BLRIC Report 88, London Community Development Foundation

Hernon P \& Dugan R (2002). An action plan for outcomes assessments in your library. Chicago, IL: American Library Association.

Kerslake E and Kinnel M (1997) The social impact of public libraries: a literature review. Community Development Foundation, Loughborough University, Community Services Group

Linley R and Usherwood B (1998), New measures for the newlLibrary: a social audit of publiclibraries. British Library Research and Innovation Report 89, Department of Information Studies, University of Sheffield, Sheffield.

Markless S and Streatfield D (2012) Evaluating the impact of your library. 2nd edn. London: Facet.

Matarasso F (1997) Beyond book issues: the social potential of library projects. Stroud: Comedia.

McClure C and Bertot J. (1998). Public library use in Pennsylvania: identifying uses, benefits and impacts. Harrisburg, PA: Pennsylvania State Department of Education.

McMenemy D (2007) What is the true value of a public library? Library Review, 56(4): 273-277.

Moray council approves $100 \%$ cut in arts funding.

https://www.theguardian.com/culture/2013/feb/13/moray-council-cut-arts-funding

(September 2018)

National Performance Framework https://nationalperformance.gov.scot/ (November 2018). Public Library Quality Improvement Matrix (PLQIM) (2005) Hamilton: Scottish Library and Information Council.

Rankin C (2012) The potential of eneric ocial Outcomes in promoting the positive impact of the public library: evidence from the National Year of Reading in Yorkshire. Evidence Based Library and Information Practice 7(1): 7-21.

Rankin C and Brock A (2012) Library services for children and young people: An overview of current provision, future trends and challenges. In: Rankin C (ed.) Library Services for Children and Young People: Challenges and opportunities in the digital age. London: Facet, pp. 3-27

Rowley J (2005) Making sense of the quality maze: perspectives for public and academic libraries. Library Management 26(8/9): 508-518.

Rubin RJ (2006). Demonstrating results using outcome measurement in your library. Chicago, IL: American Library Association.

Shirley GW (1947) William Ewart: library pioneer", Library Review, 11(4): 324-327,

Streatfield D (2012) Impact planning and assessment of public libraries: a country level perspective. Performance Measurement and Metrics 13(1): 8-14. 
Toyne J and Usherwood, B (2001) Checking the books: the value and impact of public library book reading, Department of Information Studies, University of Sheffield, Sheffield.

Vakkari, P and Serola S (2012) Perceived outcome of public libraries. Information Science Research $34: 37-44$

Van House, N (1989) Output measures in Libraries. Library Trends 38(2): 268-279.

Van House N and Childers T (1993) The Public Library Effectiveness Study: Final Report. Chicago: American Library Association. 